\title{
Engaging with participation
}

Most contemporaries dismissed Labour's attempts to accommodate demands for government to promote greater popular access to decisionmaking. Those on the New Left presumed the Cabinet opposed greater involvement in the political process; such critics adhered to Ralph Miliband's contention that the leadership was devoted to the parliamentary system and implacably hostile to those who challenged the constitutional status quo. ${ }^{1}$ Censure was not, however, restricted to the far left. The backbench MP John Mackintosh was one of an increasing number of younger revisionists who were unhappy with their government's apparent lack of interest in redistributing power from Whitehall. As one of that number, David Marquand, later claimed, they questioned the assumption 'that outcome was all and process irrelevant', and began to consider that social democracy should be about political as much as economic and social equality. ${ }^{2}$ Thus, Mackintosh believed ministers were captive to a Fabian tradition committed to the "conviction that welleducated well-disposed people' working in London were 'more likely to be right and impartial than the more remote and backward inhabitants of the provinces'.

Harold Wilson was definitely conservative when it came to constitutional matters. ${ }^{4}$ Owing to their conception of electoral politics, most of Labour's leaders saw the party's main purpose as improving voters' material conditions. The number of individuals involved in deciding how to achieve this outcome and the means by which they did so were considered second-order matters. Thus, in 1964 and 1966, consideration of how to enhance popular influence on decision-making was brief, vague and placed towards the end of the party's manifestos. What is more, proposals to reform government were framed by the need to enhance its ability to further economic growth. Yet, if increasing efficiency rather than democracy was to the fore, there was still talk of 'humanising' government and establishing a 'true partnership' between people and parliament. ${ }^{5}$ By the end of the decade, these thoughts had been expanded and given greater salience. The National Executive Committee 
(NEC) issued two strategic statements - Progress and Change (1968) and Agenda for a Generation (1969) - that emphasised the need to make the country's institutions more accountable. The NEC recognised that 'man will not live by [economic] growth alone' and accepted that post-war expansion had been achieved at the cost of creating an over-centralised state. Warning that there was no easy solution to this problem, the NEC nonetheless called for a 'fresh look at our concept of representative democracy'. ${ }^{6}$

This was not just a question of rhetoric. By the time they left office, ministers had introduced numerous reforms and fostered an impressive collection of reports and Royal Commissions, part of whose purpose was to augment the individual's influence over those decisions that most affected their lives. Within Westminster, Select Committees and a Parliamentary Commissioner had been introduced to help MPs challenge the executive. There had also been an abortive attempt to reform the House of Lords. In addition, ministers had commissioned the Redcliffe-Maud and Wheatley reports into local government; the former mooted the creation of regional councils. The government also passed the 1968 Town and Country Planning Act and subsequently issued the Skeffington report, which gave the public an unprecedented say in planning. Finally, the Cabinet approved the formation of the Crowther-Hunt Commission and charged it with putting the constitution under the microscope, with a particular eye on exploring the merits of devolving power to Scotland, Wales and the English regions.

This chapter assesses the party's response to demands for greater participation - bearing in mind the uncertainties over both the nature of what it meant exactly and how many wanted to be involved - by first examining Labour's historical attitude to the subject. It then outlines how ministers responded to its emergence as a live issue during the late 1960s, and in particular highlights Judith Hart's thinking, as she was the minister briefly in charge of the matter. The chapter then looks at those areas where increasing participation was at least discussed, such as planning, devolution, and community development. The chapter finally turns to the matter of participation within the Labour Party itself.

\section{Labour, the individual and the state}

From the start, Labour sought to use the existing parliamentary system to achieve what it could for its constituents. Yet, while the party had an instrumental view of politics, not all its members were devotees of parliament. Labour's history in fact reveals a fitful interest in constitutional reform and direct forms of representation. ${ }^{7}$ Thus, before 1914 the party was host to debates about the merits of referenda, proportional representation, abolition of the Lords and Home Rule for Wales and Scotland. 
Some hoped to promote political participation because they thought it inherent to the building of socialism. They lost out, however, to the Fabian view, that it was safer for an elite to manipulate the existing system towards progressive ends. The likes of Ramsay MacDonald feared allowing the masses to do more than just vote for the party they wished to hold office would, in the short run, hamper reform. They judged the public's opinions to be unpredictable and often reactionary. ${ }^{8}$

Even so, during the 1920s Labour remained committed to improving the efficiency of the parliamentary system and MacDonald's 1929-31 government tried to introduce a form of proportional representation (the alternative vote) for general elections. ${ }^{9}$ Although Labour briefly advocated abolishing the Lords, during the 1930s, the leadership maintained its broad acceptance of the political order. In relation to the alternatives then offered by Communism and Fascism, Westminster did not appear too bad. In addition, Labour became an enthusiast for the state ownership of much of the economy and subjecting what remained in private hands to centralised planning. This would entail a massive increase in the power of government. However, there was little sense that new forms of accountability or involvement were required. While they were not oblivious to the possibility that the state might encroach on individual liberties, Labour thinkers generally believed that, as the future member of Wilson's Cabinet Douglas Jay famously wrote, in certain instances, 'the gentleman in Whitehall really does know better what is good for the people than the people know themselves'. ${ }^{10}$

The Second World War confirmed Labour's faith in extending the state while maintaining the existing political system: the ease with which the post-war Attlee government implemented its programme further reinforced that view. ${ }^{11}$ Even the doyen of the Labour left, Aneurin Bevan, praised the unwritten nature of the British constitution because it allowed legislators to define the limits of their own authority. ${ }^{12}$ Others on the left accepted the parliamentary order with less enthusiasm. While Hugh Jenkins, who would become an MP in 1964, doubted that ballot box democracy would bring about socialism, he admitted he did not know of any better system. ${ }^{13}$ In contrast, in 1968 Michael Foot echoed Bevan's outlook when he indicated that, so far as the left was concerned, the real problem was not the character of parliament but the failure of Labour ministers to place a greater share of the economy under its supervision through nationalisation. ${ }^{14}$

Attlee's ministers believed the enlightened few could achieve progressive ends through their manipulation of an enhanced state machine operating within the established political system. Not all of them, however, thought this would be sufficient to transform society fully: to achieve that, the people had to become more involved. As the supposed arch-pragmatist Herbert Morrison declared in 1948: 
Ballot box democracy, where people go and vote - if they can be bothered and persuaded and shoved around to go and vote - every few years and do nothing in between, is out of date. We must have an active, living democracy in our country and we must whip up our citizens to their responsibilities.

This vision, however, essentially assumed 'responsible' citizens would join Labour and conform to the party's version of socialism. ${ }^{15}$ In this regard, at least, left and right were united: left-inclined bodies such as Victory for Socialism took it for granted that socialism could occur only through the party, rather than through the actions of agencies independent of it. ${ }^{16}$

Be that as it may, revisionist thinking helped ensure that, after the mid-1950s, Labour at least nodded towards pluralism, although this reflected long-standing concerns about the dangers posed by unaccountable public bureaucracies. ${ }^{17}$ The 1956 policy document Personal Freedom claimed that while Labour believed certain forms of individualism harmed the collective interest, it did not seek to create 'an all-powerful State or excessive centralisation'. Instead, it believed 'many important decisions and activities should be left to voluntary and local effort'. Given the expansion of welfare provision, contact with any number of public authorities had, however, become commonplace. Labour declared its determination that these should never 'degenerate into irresponsible bureaucracies'. Yet the proposed remedies were superficial, which was probably inevitable given the assertion that Britain enjoyed 'the most efficient, incorruptible and "non-political" Civil Service in the world' ${ }^{18}$ Not everybody thought this went far enough: MP Fred Willey, in particular, believed more needed to be done to promote 'responsible participation' and ensure the state 'continues to serve the individual', rather than the reverse. ${ }^{19}$

Labour therefore entered the 1960s armed with a particular vision of 'participation'. Members were confident that a centralised state run through Westminster would allow the party to achieve greater growth and a better redistribution of wealth. Some, however, were concerned that not enough citizens were active within the polity and that the state might be too domineering. Hope more than experience suggested that fully functioning local Labour parties in conjunction with a 'modernised' form of government would solve this problem.

\section{Attitudes to participation}

Some in the leadership certainly considered that demands for greater participation should not be taken too seriously. One of Wilson's favoured conversational themes at the time of the 1966 election was 
that the public was 'bored' with politics and wanted him to be their 'doctor who looked after the difficulties so that it could go on playing tennis'. ${ }^{20}$ Wilson's first Chief Whip, Edward Short, concurred, and considered most voters were 'just ordinary, decent folks whose first thought about every government is how it will affect them and their families': they were not 'high-minded citizens' with broad horizons. ${ }^{21}$ This sentiment was not confined to the leadership: it was a union delegate to the 1970 Labour Party conference who thought it 'a lot of bunkum' that anyone was denied the right to participate, as people could easily join their union and constituency Labour party. ${ }^{22}$

Others, if sceptical, were not wholly dismissive. Anthony Crosland considered 'participation' a 'hideously abused word' and believed only a small minority of the population wanted to influence decision-making and most of these, being middle class, were hostile to Labour. The rest, he claimed:

prefer to lead a full family life and cultivate their gardens. And a good thing too. For if we believe in socialism as a means of increasing personal freedom and the range of choice, we do not necessarily want a busy bustling society in which everyone is politically active, and fussing around in an interfering and responsible manner, and herding us all into participating groups. The threat to privacy and freedom would be intolerable.

Despite this, Crosland hoped his 1970 White Paper on local government reorganisation would encourage manual workers to become more active in local affairs. ${ }^{23}$

If Crosland was more positive about participation than he initially appeared, even those looking on the subject with more obvious sympathy agreed that only a few wanted to be active. Nor did they imagine that accommodating demands for participation required established authorities to transform themselves fundamentally. Mackintosh, for example, thought that most people simply wanted recourse to a 'clear system of accountability' and was confident that if authorities were more open in their procedures, although they might still irritate, they would at least not alienate. ${ }^{24}$ On the other hand, while Labour's 1969 Agenda for a Generation advocated individuals' 'right to be consulted about, and to influence, particular decisions which affect their daily lives', it also claimed that some decisions would still have to be taken centrally and free from local influence. ${ }^{25}$ There were, therefore, thought to be many practical limits to participation: those of popular interest, technical knowledge and ability, as well as the need to ensure decision-making was not unduly delayed and efficiency compromised. ${ }^{26}$ This meant that most Labour reformers focused on the immediate and local rather than national matters. 
While many of his colleagues also expressed their views on participation, it was the Minister for Technology, Tony Benn, who made the issue his own, through a series of speeches that laid the foundation for his post-1970 role as leader of the Labour left. ${ }^{27}$ In the early 1960s, Benn helped establish an early example of participation, the New Bristol Group. This body sought to mobilise citizens from diverse political backgrounds interested in promoting public debates about a variety of local issues. ${ }^{28}$ Significantly, however, it was in 1968, the year of Parisian student unrest and massive Labour unpopularity, that Benn systematically considered the challenge posed by new demands for participation.

Benn started from the proposition that the electorate was better educated and more self-confident than ever. This fostered a 'political individualism' that could not be fully accommodated by conventional political organisations and so gave rise to pressure groups that challenged the parties' legitimacy. ${ }^{29}$ People, he believed, were no longer 'prepared to have policy handed down from on high'; instead, they sought 'a greater say and greater voice' than allowed by the parliamentary system. The perception was that people were being 'kicked around' by those in authority and this alienation gave rise to Welsh and Scottish nationalism, student radicalism and union militancy. Yet such forces were hostile to government only because they had been denied expression within it: most just wanted to 'participate constructively' and win 'responsibility'.

Benn's proposals were, all things considered, fairly modest. First, ministers needed to recognise the electorate's intelligence and so foster a 'higher level of argument'. Politicians should tell the truth and present the full complexity of the choices to be made. Election campaigns, in addition, had to stop being 'vast marketing operations, with the voters cast in the role of consumers looking for bargain offers that give the most for the least' and instead should be the occasion for 'solemn choices'. Moreover, while the parties still had to give leadership, they needed to involve voters in decision-making. As he explained to the Prime Minister, he should not be 'Dr Wilson' but become a teacher who encouraged the people to achieve things themselves.

Benn secondly proposed that Labour should find new ways of allowing voters to influence policy-making. For example, he invited his Bristol constituents to write to him about selected issues so he could assess opinion - although he refused to be bound by the results. More ambitiously, Benn looked forward to the time when people could press a button in their homes and participate in referenda on matters of principle. Thirdly, he wanted voters to enjoy easier access to information and to that end supported moves to televise the Commons. Fourthly, greater access to television airtime should be given to voluntary bodies, like consumer groups, so they could present their views to a wider 
audience. Finally, Benn supported ceding power to the regions: before the Troubles, he believed Northern Ireland proved that the devolution of industrial policy could be economically advantageous, because local politicians better knew how to deploy resources than Whitehall.

Benn's intervention generated a largely negative response within the party. Some MPs resented his 'thinking out loud', while Wilson claimed he compromised collective responsibility by appearing to criticise government policy. Others, like Michael Stewart, claimed their Cabinet colleague had just 'dressed up a lot of old ideas as if they were new', while Judith Hart thought Benn's proposals 'too safe and dull'. Still more ministers, like John Stonehouse, looked on his notions as irresponsible and deprecated 'the current vogue of attacking institutions as though they were mainly to blame for the maladies that we suffer'. Yet, in their irritation, critics failed to notice that Benn's proposals were meant to help Labour 'lead back into the system of peaceful political change' those forces that he supposed were now operating outside it. In other words, he wanted to alter the established political system in a variety of modest ways in order to domesticate the supposed threat posed by strikers, students, nationalists and the like.

\section{Trendy Judith's Green Paper}

Benn did not have ministerial responsibility to promote participation. As one of her leading officials resentfully put it, the Prime Minister had 'publicly saddled' Judith Hart with that job when she was promoted to Paymaster General in October 1968. ${ }^{30}$ Hart's task was met with cynicism by the right-wing press, with the Daily Mail referring to her as " trendy" Judith'. ${ }^{31}$ Apart from journalistic scorn, she faced other disadvantages. In particular, with mounting by-election and municipal losses, 1968 was not the best of times for a Labour minister to show faith in the people's judgement. As Hart stated before her elevation, a Labour government was 'by its nature, a two-way process', in which 'we demand ideals and sense of purpose both from ourselves and from the community'. Given that, she believed ministers were 'entitled to a little more of both from the people than we are getting at this moment'. ${ }^{32}$ Hart also faced scepticism in her own department, where one senior official observed that ministers should look on participation as they would on virtue: 'they must always be in favour of it, and maximise it, provided the price is not too high!'33

Despite all that, Hart set about drafting some proposals. ${ }^{34}$ Reformers were, she claimed, presented with 'the most exciting opportunity open to us for 20 years to inject whatever new patterns and institutions we believe best to meet individual and community needs into a democratic 
system suffering, perhaps, from a little hardening of the arteries'. Echoing the Seebohm report on social services, Hart believed the post-war welfare state had created a new situation. At one time, income had determined the quality of an individual's health care and education, but the expansion of welfare provision meant this was now determined by government. Unfortunately, public institutions had 'failed to satisfy many of the people for whom they existed' and were 'totally inadequate' in their 'provision for user-participation'. Thus, pressure groups had grown up to represent consumers, who were better educated, free of the threat of poverty and willing to focus their energies on achieving 'direct involvement'. Rather conveniently, the Paymaster stated that, as parliament was reforming itself, she would focus on the 'peripheral area of our democratic structure', by which she meant 'town halls, education committees, nationalised industries, [and] local offices of government bodies'. What Hart termed the 'built-in unresponsiveness of outdated and inadequate institutions' had to be overcome and new patterns discovered, 'which not merely permit but invite and encourage effective participation'.

Informed by this analysis, Hart wrote a Green Paper during the spring of 1969. ${ }^{35}$ Like many others in the party, she believed few craved more involvement in decision-making but thought a larger number wanted to participate in working out the implications of agreed policies for their own communities. To that end, Hart proposed creating neighbourhood councils that would operate below established councils. These would also be smaller than the local councils proposed by RedcliffeMaud's investigation of local government (referred to below), as they would fit into areas smaller than existing municipal wards. They would: enjoy the right to be consulted by council officials, who could be called to attend meetings; have access to relevant information; and be able to nominate representatives to public bodies.

Hart's draft contained many grey areas, but in particular the exact nature of the relationship between a neighbourhood council and higher bodies was not spelt out. Moreover, while she wanted neighbourhood councils to represent an 'organic community', defining such an entity proved hard. Hart nonetheless passed her document to the Prime Minister for comment, with a mind to publishing a final version in the autumn. Wilson, however, had already told Hart the time was not ripe for concrete proposals and he was 'noticeably unenthusiastic' about her work. ${ }^{36}$ In fact, the Prime Minister was unimpressed by his Paymaster's overall performance - he described her as 'just a prattling woman who had done absolutely nothing'. ${ }^{37}$ For her pains, Hart was moved to the Ministry of Overseas Development in October 1969 and the Green Paper was not heard of again. 


\section{Participation in planning}

One criticism of the demand for more participation was that it was too vague. Hart believed Labour's proposals to enhance the public's ability to influence planning showed that participation 'can have a practical application in at least one important field'. ${ }^{38}$ The 1968 Town and Country Planning Act gave the public the chance to make representations that authorities had to take into account at a much earlier stage than hitherto. With no little hyperbole, this stipulation was described by Arthur Skeffington, a junior minister at the Ministry of Housing and Local Government, as 'a new Magna Carta in planning' ${ }^{39}$

The Committee on Public Participation in Planning, chaired by Skeffington, was established to determine how authorities should facilitate expression of the public's new voice and published its recommendations in July 1969. While Skeffington underlined how important it was that the public enjoyed adequate means of influencing planning, he still believed responsible authorities should retain the final say. His proposals were aimed at directing the people's talents into 'constructive channels', so that planning could be 'collaborative and friendly' and allow people and planners to realise they were on the same side. ${ }^{40}$ Skeffington's proposals nonetheless proved contentious, in particular those relating to the creation of community forums and the appointment of community development officers. The object of the former was to gather together local voluntary associations to help them present their views; the role of the latter was to mobilise the opinions of individuals belonging to no formal organisation - which in practice meant helping working-class residents make a case.

The Skeffington report was written in such a way as to win over authorities sceptical of the need for greater participation. ${ }^{41}$ Despite this, many remained opposed and, while not all were against the forums, they were almost universally hostile to development officers. The London Boroughs Association, for example, believed the latter were superfluous, thinking 'the individual's right not to comment should be accepted', while the Urban District Council Association argued that 'if it is to be genuine and of real value', participation 'must be voluntary and not induced' ${ }^{42}$ In contrast, most voluntary organisations welcomed the report: the National Federation of Women's Institutes considered Skeffington had created 'opportunities for intelligent and constructive comment [that] would help and overcome public apathy' ${ }^{43}$ Hart was especially enthusiastic about development officers and wanted their function extended, so they could promote community development 'as an active and positive function' ${ }^{44}$

Ministers found it difficult to take account of such contradictory comments when constructing a circular to be issued to planning authorities. 
Officials were still grappling with the task when Labour lost power. They had, however, prepared a draft that ceded most ground to Skeffington's critics, as neither forums nor development officers were made obligatory. Authorities were instead expected to take steps to ensure they consulted a cross-section of the public about any proposal; how this was to be achieved was left to them. ${ }^{45}$ This was undoubtedly a step back from what had been promised: if the 1968 Act still represented a new Magna Carta, King John had regained many of his powers.

\section{Responding to nationalism}

Some Labour members reacted to the post-1966 by-election successes of the Scottish National Party (SNP) and Plaid Cymru by suggesting the party should embrace legislative devolution. Given that the likes of Keir Hardie had supported Home Rule, advocates claimed they were just 'reaffirming' a 'basic Labour policy' that had been temporarily cast aside. ${ }^{46} \mathrm{~A}$ few argued that limited self-government was consistent with democratic socialism, as it would promote participation in decisionmaking and develop responsibility. ${ }^{47}$ Others, however, looked on any measure that threatened to break up the United Kingdom as, at best, eccentric. Even Benn (albeit in 1967) argued that, as satellites could circumnavigate the earth in ninety minutes, it was 'a little odd to press for further disintegration of government'. ${ }^{48}$

Appeasing nationalist sentiment was, moreover, viewed with suspicion, for nationalism was considered an irrational and ultimately violent force, the very antithesis of enlightened democratic socialism. Thus, in 1959 activists in the Labour-Liberal marginal seat of Merioneth were most exercised not by their closest rival but by Plaid's 'wild dreams'. ${ }^{49}$ After 1966, Labour's rhetoric became more vituperative but undoubtedly reflected genuine concern. Arthur Woodburn, Attlee's Secretary of State for Scotland, pronounced the SNP guilty of 'race hatred' and, drawing parallels with the Nazis, asserted that if nationalists achieved their end, they would spark a civil war. ${ }^{50}$ When extremists set off bombs in Wales, one regional official considered this vindicated similar fears, and described such acts as the inevitable result of Plaid's purportedly hysterical language. ${ }^{51}$ There was, in addition, the suspicion that once the British labour movement was fragmented into national units, it would be seriously weakened. As the party's Scottish Council put it in 1969, Labour's 'strength lies in unity; a unity which transcends the narrow limits of prejudice and nationalism, and reaches out towards a Democratic Socialist Commonwealth'. ${ }^{52}$

The essential basis for Labour's case in favour of the Union was economic. For example, the centralised policies pursued by the Attlee 
government were credited with rescuing Scotland and Wales from mass unemployment. Many outside England saw salvation in the further concentration of economic power in the hands of the British state and then enhancing their influence within the Whitehall machine that ran it. Certainly, before 1966, economic criteria were the only ones that appeared to exert any force. Thus, during the 1950s, the Welsh Regional Council of Labour rejected calls for a separate parliament but supported the case for a Secretary of State on the grounds that while the former would harm prosperity in the principality, the latter would have the opposite effect. ${ }^{53}$ Similar considerations led Labour's Scottish Council to reject a devolved legislature. Forced to clarify its position in 1958, it asserted that while centralisation had not eliminated all Scotland's problems, those that remained would 'best be solved by socialist planning on a United Kingdom scale'. Citing the view of the Scottish TUC (STUC), it argued that 'economic security remains the primary factor for the Scottish people' and that could be achieved only if they remained fully integrated within the British economy and properly represented at Westminster. ${ }^{54}$

Given this frame of reference, it was not surprising that many saw nationalist success as a reflection of how the government's economic policies were hurting voters. The cuts in spending and insistence on wage restraint after July 1966 were widely resented across the United Kingdom, which saw unemployment rise, particularly in industrial Wales and Scotland. In England, it was argued, disaffected voters turned to the Conservatives, but elsewhere they used the nationalists to vent their feelings. Given the supposedly negative nature of SNP and Plaid support, once the government's policies began to work it would, as one minister put it, 'evaporate'. It was therefore unnecessary to address the issue of constitutional change; indeed, given that it would only encourage nationalists, such a course was dangerous. ${ }^{55}$

Others were not so confident that nationalist support would disappear - but agreed its rise reflected problems general to the United Kingdom. In arguing for Scottish legislative devolution during the late 1950 s, Mackintosh proceeded from the assumption that all Britons wanted to control the expanded post-war state bureaucracy. His solution was to create a number of elected sub-parliaments, to bring government closer to the people; these would enjoy responsibility for most internal issues, leaving Westminster to deal with economic planning, defence and foreign policy. Labour's 1967 Hamilton by-election defeat was due, he believed, to the fact that this feeling of 'remoteness' from government had not yet been addressed. ${ }^{56}$

Some did think the rise of nationalism said something specific about the situation in Wales and Scotland. Even so, while they did not make the connection, much of their analysis was applicable to other parts of 
industrial Britain, where Labour also enjoyed a virtual monopoly of elected office. Gwilym Prys Davies, the party's candidate in the 1966 Carmarthen by-election, believed Labour representatives had alienated the young - presumed to be a core nationalist constituency - because they had become the 'new conservatives'. Labour in Wales, he stated, was merely committed to maintaining the status quo. ${ }^{57}$ Adopting a slightly different tack, James Griffiths, Welsh Secretary of State during 1964-6, came to a similar conclusion. He believed rising unemployment had created a sense of helplessness among established Labour voters, although Griffiths also accepted that the party no longer represented the kind of idealistic cause to which he supposed the young were attracted. Thus, like Prys Davies, Griffiths thought Labour needed to embrace a 'constructive alternative' to independence or was 'doomed to disappear' in the principality. ${ }^{58}$ In Scotland as much as in Wales, one of Labour's most intractable problems was that it had held on to power in many local authorities for a number of generations: the party's municipal record was hardly unblemished, while accustomed electoral success bred complacency and a frail organisation - most especially in Glasgow. ${ }^{59}$

While some were exercised by how to respond to nationalism, it would be wrong to imagine Labour's predicament appeared acute to everybody. During the later 1950s, it was unsurprising that Edinburgh Fabians did not think devolution or independence important enough to devote even one of their many speaker meetings to. ${ }^{60}$ More unexpectedly, Edinburgh South's general management committee (GMC) entirely disregarded the question of Scottish government throughout the 1960s. The one time constitutional change figured on its agenda was when members asked Edinburgh City Party to counter SNP propaganda ${ }^{61}$ More generally, immediately before the Hamilton by-election only one resolution on Scottish government was submitted to the 1967 Scottish party conference. In contrast, in 1968 ten such resolutions albeit out of seventy-two - were submitted. Of these, however, only two favoured a devolved legislature, while a further two simply wanted nationalist arguments refuted. The remainder just called for greater administrative devolution, such as holding meetings of the Grand Committee in Edinburgh and moving more civil servants north of the border. As they submitted only one resolution on the topic in 1969, presumably most members' interest had by then been exhausted. ${ }^{62}$ Measured in terms of resolutions submitted to their conference, Welsh activists were more concerned with rising unemployment; in comparison, Cardiff's relationship with Westminster was insignificant. ${ }^{63}$

This lack of interest suited the Scottish Council executive, which was reluctant to amend the approach outlined in 1958. ${ }^{64}$ The Hamilton reverse forced the hierarchy to promise to consider the question 'anew', 
although this resulted in a simple reiteration of policy. After the unprecedented - if still limited - interest shown at the 1968 Scottish party conference, support for further administrative devolution was mooted and the matter was placed in the hands of a sub-committee. If this was not a delaying tactic it looked like one, for members took eighteen months to decide that any type of elected legislature was unwise. As a concession to new thinking, however, they supported local government reform and called for the powers of the Scottish Office to be enhanced. Even these modest proposals appeared dangerous to many Scots MPs. ${ }^{65}$

Those advocating a new relationship with Westminster despaired of such thinking. Mackintosh was no friend of nationalism and had long argued that an elected assembly for Scotland would be a bulwark against it. Such an arrangement, he argued, would be efficient and meet the democratic needs of the people, while Scots MPs could still play a full part in debating national economic issues. Regionalism would also be a fillip to Labour's wider ambitions, for voters would never support a radical reduction of inequality if they believed government was run by a remote bureaucracy which did not have their interests at heart. ${ }^{66}$ The end of the 1960s saw the revisionist Mackintosh joined by others drawn from the party's left, like the MP Alex Eadie and future MP Jim Sillars, who took a firm line against independence but who nonetheless endorsed the establishment of regional authorities. ${ }^{67}$ Yet even advocates of a devolved Scottish parliament accepted that prosperity depended on 'socialist planning for the whole of Britain' ${ }^{68}$ Activists in Edinburgh even justified a parliament on the grounds that it would rebuild public 'respect' for government, and suggested devolution was a 'natural' evolution of existing arrangements. ${ }^{69}$ Despite their moderation, these voices nonetheless remained on the periphery of the Scottish debate.

In Wales matters were more dynamic, if only because the principality lacked the same degree of autonomy long enjoyed by Scotland. Labour entered the 1959 campaign committed to creating a Welsh Office, and made good this promise in 1964. The Secretary of State for Wales, however, enjoyed fewer powers than the Scottish counterpart, something that rankled with many, who continued to push for additional powers short of devolution. In particular, they called for the Welsh Economic Council to assume more responsibility and even for it to be directly elected, a view endorsed by Cledwyn Hughes, Secretary of State during $1966-8 .^{70}$ While its recommendations were watered down, the study group established by the Welsh party to investigate the machinery of government favoured creating an elected parliament that would share responsibility for economic planning with Westminster. ${ }^{71}$ The appointment of George Thomas as Secretary of State in 1968 indicated that Downing Street did not welcome such thinking. Instead of dallying with constitutional matters, Thomas focused his attention on ensuring the 
success of the investiture of the Queen's eldest son as Prince of Wales in July 1969. This blatant example of an 'invented tradition' was devised with at least two eyes on mobilising unionist opinion within the principality: indicating the weakness of nationalism in Wales, it proved to be a great success.

\section{A federal United Kingdom?}

As Lord President of the Council, Richard Crossman was responsible for co-ordinating the government's response to nationalism. ${ }^{72}$ Crossman believed that, in the short term, administrative devolution should be accelerated. He did not, however, think this would solve the fundamental problem exposed by Labour's electoral reverses, for, echoing the views of those like Mackintosh, he believed the main cause was the failure of established political institutions to relate to new popular demands for greater self-government. If this was more obvious in Wales and Scotland, it was evident in England, too, and called for a radical solution, which, Crossman believed, was the creation of a federal United Kingdom, with power dispersed to elected regional assemblies. Before moving to this end, however, he felt it wise to wait for the publication of the Redcliffe-Maud and Wheatley commissions on local government in England and Scotland, respectively. These tackled related issues and Crossman feared that if ministers pressed on without the benefit of their insights, they would be accused of trying to placate nationalism through unprincipled expedients.

Unfortunately for the Lord President, the Redcliffe-Maud and Wheatley reports were not published until the summer of 1969 and his Cabinet colleagues were keen to apply an immediate palliative to dampen down nationalism. To that end, the Home Secretary, James Callaghan, a man with little interest in constitutional matters, together with the Secretaries of State for Wales and Scotland, pushed for the immediate announcement of a constitutional commission. ${ }^{73}$ The establishment of this body, with an extensive - some might think deliberately overambitious - remit, under the chairmanship of Lord Crowther-Hunt would, Callaghan claimed, allow the government to "establish the facts' ${ }^{74}$ If the commission delayed the moment when decisions needed to be taken, it nonetheless gave the impression ministers had taken heed of public opinion.

While federalism did not excite many of Crossman's colleagues, it enjoyed some support among English Labour activists. Advocates included T. Dan Smith, former leader of Newcastle City Council and of the Labour Party's Northern Region. Encouraged by the experience of regional economic planning councils established under the aegis of 
the Department of Economic Affairs, leading lights in the North East considered elected regional government 'essential'. Using economic arguments in a way contrary to that employed in Scotland, they claimed that if their region was to overcome its many problems, it needed greater responsibility for planning. Although they still believed central government should retain overall control of planning, they argued that its detailed application could be the job of assemblies accountable to the voters. Autonomy, of course, had its limits and it was thought taxation should not be levied at the regional level - if only because it would leave the troubled North East even poorer. ${ }^{75}$ Indicative of divisions few in the national leadership wanted to expose, members in the affluent West Midlands also wanted an elected regional council - but one armed with the power to levy income tax. ${ }^{76}$

Federalism, however, faced formidable opposition outside the Cabinet, in the form of most trade unions. They believed devolution would undermine disadvantaged regions, as it would expose the extent to which Westminster redistributed wealth from the better-off areas to the poorest. Thus, while it might increase democracy, federalism would exacerbate Britain's uneven economic development. ${ }^{77}$

Despite everything, Labour's formal attitude to devolution did not much change during 1964-70. There was support for measures, such as the 1967 Welsh Language Act, that accommodated cultural difference. However, many in Wales feared a devolved parliament with legislative powers would undermine the ability of Welsh MPs to influence Whitehall and so harm the national interest. ${ }^{78}$ In Scotland, the issue moved an even shorter distance: echoing the views of the party's Scottish Council, the chair of Edinburgh West CLP claimed that only one factor would revive Labour's fortunes north of the border: economic recovery. ${ }^{79}$

\section{Reforming local government}

The slow progress of the Redcliffe-Maud Commission on the Reform of Local Government in England, as well as of other investigations into the situation in Wales and Scotland, was one legitimate reason why ministers were unwilling to allow discussion of federalism to develop too quickly. The commission was known to be considering regional government, although it was taking its time: it sat for over three years and its report was not published until June 1969. The commission was Wilson's response to concern about the relevance of local government, for when Attlee nationalised utilities such as gas and water, then created a National Health Service, he stole many of the municipal authorities' responsibilities. It is no wonder that, by the mid-1960s, most local contests provoked the participation of little more than one-third of the electorate. 
Introducing the Redcliffe-Maud report, the Prime Minister rightly described it as recommending the 'most far-reaching reorganisation of local government the country has ever seen'. Wilson particularly welcomed its proposals to rationalise a confusing array of bodies, something he hoped would create more effective authorities. He also correctly predicted that some of the report's proposals would be contentious, although he did not say this would be especially true in his own party. ${ }^{80}$ While the Commission raised the possibility of regional government and suggested new means by which people might participate at the grass roots, RedcliffeMaud was seen as further centralising power and as being interested in efficient rather than democratic administration. ${ }^{81}$

The report's main recommendation was to create three tiers of administrative responsibility. It proposed that England (excluding London) should have its current 1,200 elected bodies replaced by just sixty-one, all but three of which would have exclusive responsibility for services. Given their size, Birmingham, Manchester and Liverpool were granted metropolitan status, which meant they would share service provision with a number of smaller councils. These sixty-one bodies were each to appoint some of their members - and co-opt a smaller number of outside experts - to eight provincial councils. Wheatley made similar proposals for regional government in Scotland. Building on the Department of Economic Affairs' regional economic planning councils, their main role was to lie in economic planning and development. Below these two layers, Redcliffe-Maud suggested a third, composed of local councils of various sizes with limited and mostly undefined responsibilities.

Labour was divided over the report. Wilson was attracted to the creation of newer, fewer and (he presumed) more efficient local authorities. However, George Thomson, whom the Prime Minister charged with assessing party opinion, detected a 'depressingly conservative response' among councillors and activists. Not only did they fear for their own prospects as a result of the boundary changes required by reform, but they had also become attached to administrative units with venerable traditions, and opposed their abolition. Crosland similarly noted that the proposed reduction of councillors - numbers were set to drop from 32,000 to 7,000 - caused 'dismay' within the ranks. Given their influence in CLPs, Thomson warned the Prime Minister that he needed to take full account of councillors' views when drafting legislation. Transport House was consequently persuaded to arrange a series of regional conferences designed to win over critics. ${ }^{82}$

Such was the concern in Bristol West, its GMC devoted two meetings to the subject, which confirmed Labour activists' largely critical response to Redcliffe-Maud. The future MP Michael Cocks feared rural areas would enjoy undue weight in the provincial councils and so loosen Labour's already precarious grip on local government in the South West. 
He also believed the report 'had an air of Civil Service thinking about it', inasmuch as it gave too much power to chief executives and appointed members, as opposed to elected representatives. Some called for municipal authorities to be reshaped to allow people to participate actively, believing it was better to have more democracy even if was at the cost of efficiency. Paradoxically, however, Cocks did not want Whitehall to give up too much power to the provincial councils, as he feared the quality of services would then vary across the country - an understandable fear for a Labour activist in a region where the Conservatives were likely to dominate. In the end, the GMC agreed to support a motion that rejected the report on the grounds that it would concentrate power in too few hands..$^{83}$

Labour's 1969 conference revealed that many activists believed the report sacrificed democracy 'on the altar of efficiency'. If applied, they feared a worsening of the 'apathy and feeling of cynicism felt by many people, the feeling of remoteness that the elector has to even his town or civic hall'. The provincial councils would be undemocratic, the unitary authorities too big and local councils toothless. ${ }^{84}$ Those 1,000 members who attended Labour's eight regional conferences held on the subject during October generally supported that view. Given the earlier discussion on devolution, it will be no surprise that their overwhelming view was that provincial councils should be directly elected. Especially from the North and the West Midlands came the call to be granted legislative powers. Members were also sceptical about the proposed local councils and regarded them as functionless sounding boards for local opinion. If they were to be more than that, their powers needed to be defined and enhanced..$^{85}$

As the minister responsible for local government, and latterly participation, Crosland had his own doubts about Redcliffe-Maud. His White Paper, published in February 1970, reflected some of those misgivings. ${ }^{86}$ In particular, Crosland appeared only too happy to wait for the Crowther-Hunt Commission to report before pronouncing on provincial councils. Possibly influenced by Hart's abortive Green Paper, he nonetheless made some concrete proposals with regard to local councils, suggesting they should be created throughout all unitary areas although in metropolitan districts these should come into being only if demanded by residents. Although he was unwilling to give them responsibility for providing services, Crosland ensured they could play a part in their administration. More generally, he presented the White Paper as giving authorities greater freedom from central government. While they would have to conform to certain national policies - such as the introduction of comprehensive education - they would be free of detailed supervision in a variety of areas and enjoy unprecedented financial autonomy. ${ }^{87}$ 


\section{The Community Development Programme}

While usually thought of as a flawed experiment in welfare provision, the Community Development Programme (CDP) also indicated how far ministers were willing to recast the relationship between individual and state. ${ }^{88}$ It was not a Labour scheme but originated in the work of the Home Office Children's Department and was largely the initiative of Derek Morrell, an official described by Crossman as 'of quite unusual administrative drive combined with a mystical imagination'. ${ }^{89}$ Yet the fact that the CDP saw the light of day showed how far the government even conservative figures like James Callaghan - was willing to sponsor innovation.

The essential aim of the CDP was to discover new ways of meeting the needs of those apparently suffering from 'multiple deprivation' and so dependent on the welfare state. It was thought such groups remained trapped in poverty partly because welfare agencies had failed to coordinate their efforts, so the CDP relied on an inter-service team, including local and national bodies. Most innovative, however, was its stress on the need to involve the poor in guiding the project and ensuring welfare providers actually met their needs. ${ }^{90}$ As Crossman put it, the CDP would help the poor 'stand more on their own in the future by their own efforts, without having to rely so much on external support', as it would encourage 'mutual help and voluntary effort' within local communities. ${ }^{91}$ Thus, while an example of state intervention, its purpose was to empower the poor and help them 'exercise more control over their lives'. ${ }^{92}$

Callaghan launched the scheme in January 1969. It was meant to embrace twelve pilot areas, each of which would enjoy a generous degree of autonomy from Whitehall, to allow them to reflect residents' self-defined interests. In the spring, four councils were invited to participate, the object being to have another four up and running by October 1970. However, by the time Labour left office only two projects Liverpool and Coventry - were properly established and it was not until Wilson was back in power in 1974 that the target number of projects was met. ${ }^{93}$ One reason for delay was the reluctance of most local authorities, for, while mostly funded from a $£ 20$ million budget, each project still required some municipal expenditure. Local officials were also afraid of giving away too much control; Coventry's Director of Education, for example, predicted 'permanent instability' if too much store was put in residents' opinions. Finally, consultations with council officials, local agency representatives and, especially, residents had to be protracted to ensure each side fully co-operated. ${ }^{94}$ In particular, determining who represented the 'community' proved problematic. In Liverpool, the influential Catholic Church-dominated Scotland Road 
Residents Association claimed to speak for locals, but officials doubted that. ${ }^{95}$ In Coventry's Hillfields district there were three neighbourhood organisations but the CDP director thought co-opting them would smack of a nominal form of 'community' involvement. However, he appreciated that picking those he considered best suited to the task was also unsatisfactory. ${ }^{96}$

The election of a Conservative government in June 1970 did not help the development of the CDP and resulted in the project being shifted from its original administrative home. This compounded problems associated with high levels of personnel turnover and unwieldy steering groups that appeared to find decision-making traumatic. Moreover, from the outset, the principle on which the CDP was based had been criticised by those influenced by 'radical' sociology. Even the academic charged with co-ordinating CDP research believed the assumption that the poor could be helped to improve their position within the existing system was a 'shibboleth of liberal society in decline'. ${ }^{97}$ Others praised its aims but considered that, without any conflict between deprived communities and the state, the poor would never achieve improvement. Despite the intention to help the poor help themselves, these detractors considered it was based on a patronising 'missionary approach' ${ }^{98}$ Many social workers employed by the projects adhered to these views and refashioned - or Callaghan believed misused - them to suit their own agendas. If such attempts to radicalise the poor failed to improve their lives, they nonetheless gave CDP employees a base from which they could transform inner-city CLPs during the 1970s. ${ }^{99}$ Thus, two years after all twelve projects had been finally established, the CDP was closed down and dubbed a dismal failure, even by progressive Labour figures such as the Home Office minister Alex Lyon. ${ }^{100}$

\section{A participatory party?}

Despite the assumptions of many in the party, it was uncertain how far CLPs were the best means of fostering wider political participation. Most working-class members exhibited what some considered a 'natural quietism', in that they rarely challenged even representatives who went against their wishes. Others believed there was so little evidence of members making any impact on government policy that party democracy was a myth. ${ }^{101}$ Activists were certainly frustrated by Wilson's refusal to take heed of conference; as one noted in 1969, CLPs contained those 'who work like hell for the Labour Party to keep it financially sound [but] ... who frankly are ignored on so many occasions when the question of policy has to be discussed'. ${ }^{102}$ At least some ministers believed this the proper state of affairs. Short, for one, believed the NEC - and 
presumably the party as a whole - should confine itself to acting as the government's 'cheerleader'. Wilson's own conception of consulting members was limited to attending meetings, where he would listen to activists' complaints, then sign autographs. ${ }^{103}$

If the party's internal procedures were problematic, by the end of the decade an increasing number were concerned that many CLPs were 'claustrophobic and inward-looking' and so unable to give voice to local residents. ${ }^{104}$ They needed, it was said, to involve themselves more closely in community action and help build 'a more effective grass roots social democracy'. Members should become involved in every aspect of society, 'right down to the ordinary, everyday things of ordinary people's everyday lives'. MP and NEC member Tom Bradley stated that local parties should support tenants' associations, so that residents could appreciate that Labour would 'fight with them, not just for higher wages and better conditions, but for a cleaner, more civilised environment and for a say in how hospitals, schools and factories are run'. Some were more interested than others in exploring these possibilities. Labour-controlled Sheffield Council was one of the few to form a committee on which sat members of the Housing Committee and tenants' groups, which had the power to recommend action. ${ }^{105}$

Transport House had always appreciated that a healthy organisation required an informed and enthusiastic membership. In the late 1960s, officials sought new means to overcome members' ignorance of policy and alienation from policy-making. ${ }^{106}$ Even old hands such as the regional organiser Jim Raisin believed Labour required a 'genuinely democratic structure'. ${ }^{107}$ With that in mind, in 1969 the Home Policy Sub-committee recommended a scheme, referred to as Participation '69, that involved circulating a background document to local organisations along with a questionnaire to be submitted to the NEC. According to one critical observer, this was 'the first new approach to party democracy since 1918 ' ${ }^{108}$ Even so, if its main purpose was to give members a more direct say in policy-making, officials hoped it would also enlighten them as to the difficult decisions faced by ministers and so create a greater degree of empathy for their leaders. ${ }^{109}$

The first topic selected for discussion was women and social security. Armed with members' responses, the NEC proposed to brief MPs in time for a forthcoming Commons debate on the issue. A discussion document and questionnaire were duly despatched to 2,000 local parties, women's sections, Young Socialist branches and affiliated unions, who were all urged to debate the subject. The response was rather disappointing. Only 198 questionnaires were returned by the deadline, although over 250 were eventually submitted; it was calculated that 2,343 individuals had taken part in discussions. The NEC nonetheless considered this a helpful first step in a procedure it wanted to become 
an established feature of policy-making. Discussion of the second topic economic equality - was, however, disrupted by the 1970 election campaign and the documents were never circulated to members. ${ }^{110}$

\section{Conclusion}

Labour's 1970 manifesto devoted five pages to policies designed to make Britain an 'active democracy' and announced how seriously the party took the need to 'infuse a democratic element into the increasingly complex institutions which dominate our lives'. ${ }^{111}$ While it is usually unwise to place much credence in the contents of a manifesto, it would be churlish to dismiss this as constituting no more than a rhetorical shift. Although Labour's response to demands for greater participation was more ambivalent and limited than some wanted, its engagement was much more positive than often supposed.

It would still be fair to stress how far the party had not moved and the extent to which any shift in position was the result of ministers' desire to appease apparently powerful electoral forces. Thus, despite Labour ministers' 'pious words', by 1970 Mackintosh considered Britain remained one of the most centralised of industrial societies. ${ }^{112}$ Labour's was an open-ended legacy, one consisting of a generous number of Royal Commissions, reports, experimental projects and White Papers, but comparatively little substantive change. At least some of this was deliberate: for many ministers, investigating the 'facts' was preferable to tackling tricky issues head on. The likes of Wilson were largely uninterested in changing the process, being preoccupied with manipulating the existing mechanics of decision-making. Even so, the Prime Minister still gave colleagues limited scope to develop ideas that echoed radical opinion outside government.

Change in this matter, above all others, was protracted - possibly inevitably so - and Labour in office had taken but a few faltering steps by June 1970. As Judith Hart warned in relation to the Skeffington report, even after some reform the people 'will continue to show the irrationality and ingratitude which is their right as citizens'. Moreover, 'for a long time all that will be possible to demonstrate as a result of the whole effort will be a little more understanding and give and take here and there'. However, at least there might be 'a willingness on the part of the authorities to take the public into their confidence rather more fully and at an earlier stage than hitherto'. ${ }^{113}$ As Hart was an enthusiast for innovation, it is no wonder that many others, inherently sceptical about the need for change, preferred to cling to the familiar ways of doing politics rather than take such a leap into the dark. 


\section{Notes}

The place of publication is London unless otherwise specified.

1 R. Williams (ed.), May Day Manifesto 1968 (Harmondsworth, 1968), pp. 143-50; R. Miliband, Parliamentary Socialism (1972), p. 13.

2 D. Marquand, 'Reaching for the levers', Times Literary Supplement, 11 April 1997.

3 National Library of Scotland (NLS), John P. Mackintosh papers, Dep. 323/ 231, Democracy and the devolution of power, n.d. (but late 1960s).

4 See, for example, H. Wilson, The Governance of Britain (1977).

5 Labour Party, Let's Go With Labour for the New Britain (1964), pp. 22-3; Labour Party, Time for Decision (1966), pp. 18-19.

6 Report of the Sixty-Seventh Annual Conference of the Labour Party (1968), pp. $340-2$.

7 M. Taylor, 'Labour and the constitution', in D. Tanner, P. Thane and N. Tiratsoo (eds), Labour's First Century (Cambridge, 2000).

8 L. Barrow and I. Bullock, Democratic Ideas and the British Labour Movement, 1880-1914 (Cambridge, 1996).

9 P. Joyce, Realignment of the Left? A History of the Relationship Between the Liberal Democrat and Labour Parties (1999), pp. 70-2; N. Riddell, Labour in Crisis. The Second Labour Government, 1929-31 (Manchester, 1999), pp. 137-9.

10 D. Jay, The Socialist Case (1947), p. 258.

11 S. Fielding, P. Thompson and N. Tiratsoo, 'England Arise!' The Labour Party and Popular Politics in 1940s Britain (Manchester, 1995), pp. 86-8.

12 A. Bevan, In Place of Fear (1952), pp. 100-2.

13 British Library of Political and Economic Science, Hugh Jenkins papers, 6/9, Socialism, democracy and the Labour Party, n.d. (but 1955).

14 M. Foot, 'Credo of the Labour left - interview', New Left Review, 49 (1968), pp. $28-9$.

15 S. Fielding, 'Labourism in the 1940s', Twentieth Century British History, 3:2 (1992), pp. 145-7.

16 H. Jenkins and W. Wolfgang, 'Tho' cowards flinch', Victory for Socialism Pamphlet (1956).

17 W. B. Gwyn, 'The Labour Party and the threat of bureaucracy', Political Studies, 29 (1971).

18 Labour Party, Personal Freedom (1956), pp. 7-9, 11-12.

19 London Metropolitan Archive (LMA), London News, July 1956.

20 T. Benn, Out of the Wilderness. Diaries, 1963-67 (1987), p. 422.

21 E. Short, Whip to Wilson (1989), p. 110.

22 Report of the Sixty-Ninth Annual Conference of the Labour Party (1970), p. 277.

23 A. Crosland, 'A social democratic Britain', Fabian Tract, 404 (1970), pp. 12 15; The Times, 25 September 1970.

24 Mackintosh papers, Democracy.

25 Report of the Sixty-Eighth Annual Conference of the Labour Party (1969), pp. $388-9$.

26 Editorial, 'Participation', Socialist Commentary, December 1968.

27 For more on Benn during this period, see L. Panitch and C. Leys, The End of Parliamentary Socialism (1997), pp. 39-65.

28 For more on the Group's activities, see Bristol Record Office (BRO), Bristol South East CLP papers, 39035/146, New Bristol Group, Output 1962/63 (Bristol, 1963), Output 1963/64 (Bristol, 1964) and Output 3 (Bristol, 1966).

29 This account is based on: T. Benn, Office Without Power. Diaries, 1968-72 
(1988), pp. 59, 67-8, 73, 81, 107-13, 122; The Times, 19 April and 13 May; Guardian, 23 March, 10 June and 6 November; Observer, 26 May; Daily Telegraph, 6 November 1968.

30 Public Record Office (PRO), CAB 151/58, R. Jardine, Participation, 3 December 1969.

31 Daily Mail, 18 October 1968.

32 Labour Party Archive (LPA), Judith Hart papers, File Hart 10/4, Section 10, Speech to rally of Sudbury and Woodbridge CLP, 18 May 1968.

33 CAB 151/57, Jardine to Barnes, 17 August 1969; CAB 151/58, Jardine, Participation.

34 The following two paragraphs are based on CAB 151/57, Speech to the Council of Social Services, in Survey of British and Commonwealth Affairs, 10 (October 1969), and Notes on participation, February 1969; CAB 151/58, Notes for speech to the Council of Social Services, 19 September 1969; Hart papers, File Hart 10/4, Section 10, Speech to London conference, 9 June 1968; Benn, Office, p. 121.

35 CAB 151/57, R. Jardine, Note for record, Local councils, n.d.; Outline of Green Paper on participation; Hart papers, Section 12, File 13, R. Jardine, Note for record, n.d.

36 PRO, PREM 13/2713, Note of a meeting between the Prime Minister and the Paymaster General, 24 March 1969; CAB 151/58, Barnes to Jardine, 25 November 1969; CAB 151/58, Jardine, Participation.

37 Benn, Office, p. 193.

38 CAB 151/63, Hart to Greenwood, 10 July 1969.

39 CAB 151/63, Press release for speech by A. Skeffington, 17 September 1969.

40 PRO, HLG 120/1045, Press release for a speech by A. Skeffington, 23 September 1968; CAB 151/63, Press release for Skeffington.

41 HLG 136/274, Sub-committee on public participation, Note of first meeting, 29 May 1968.

42 For these and other responses, see HLG 136/308.

43 HLG 136/309, Witall to Corrie, 26 January 1970.

44 CAB 151/63, Hart to Greenwood, 10 July 1969.

45 PRO, AT 35/51, Public participation circular (revised draft), 12 June 1970.

46 Sixty-Seventh Annual Conference of Labour, p. 174.

47 National Library of Wales (NLW), Labour Party of Wales papers, file 106, G. D. Purnell, Notes for study group, Reform of machinery of government, Socialist attitude to government, n.d. (but 1969).

48 NLW, MS 23699, f.118, Benn to Ifor Jones, 20 March 1967.

49 NLW, Merioneth CLP papers, Annual report and statement of accounts for the year ending 31 December 1959.

50 Scotsman, 22 February 1968; A. Woodburn, 'The rise of Scottish nationalism', Socialist Commentary, June 1968, p. 9; Alloa Journal, 15 November 1968.

51 NLW, Brynmor John papers, 19, G. Jones, Extremism in Wales, 3 July 1969.

52 Labour Party Scottish Council, Scottish Government. Interim Report (Glasgow, 1969), p. 23.

53 Welsh Regional Council of Labour, Labour's Policy for Wales (Cardiff, 1954), pp. 3-4; R. M. Jones and I. R. Jones, 'Labour and the nation', in D. Tanner, C. Williams and D. Hopkins (eds), The Labour Party in Wales, 1900-2000 (Cardiff, 2000), pp. 249-52, 254-5.

54 M. Keating and D. Bleiman, Labour and Scottish Nationalism (1979), p. 146; M. Keating, 'The Labour Party in Scotland, 1951-1964', and F. Wood, 'Scottish Labour in government and opposition, 1964-79', in I. Donnachie, C. Harvie and I. S. Wood (eds), Forward! Labour Politics in Scotland, 1888- 
1988 (Edinburgh, 1988), pp. 91-2, 97-8, 101; Labour Party Scottish Council, Special Report on Scottish Government (Glasgow, 1958), pp. 3, 11.

55 D. Douglas, 'The lessons of Pollock', Socialist Commentary, April 1967; and K. Morgan, 'Inaction for Wales', Socialist Commentary, June 1967; CAB 130/ 390, Minutes of meetings held to discuss devolution to Scotland and Wales, 18 July, 23 and 28 October 1968.

56 Scotsman, 27 April 1957; Mackintosh papers, Dep 323/47, Transcript from 'Ten o'clock', transmitted 3 November 1967, BBC Radio 4.

57 NLW, James Griffiths papers, C/3/14, G. Prys Davies, A memorandum on the political situation in Wales, 12 November 1967, pp. 1-2.

58 Griffiths papers, C/3/18, J. Griffiths, The political situation in Wales, October 1968.

59 J. Connell, 'Collapse in Scotland?', Socialist Commentary, January 1969.

60 NLS, Edinburgh Fabian Society papers, Acc 4977/15, passim.

61 NLS, Edinburgh South CLP papers, Dep 203/5, GMC minutes, 28 December 1967.

62 Labour Party Scottish Council, Report of the Executive Committee to the 52nd Annual Conference (Glasgow, 1967), p. 77; Report of the Executive Committee to the 53rd Annual Conference (Glasgow, 1968), pp. 45-7; and Report of the Executive Committee to the 54th Annual Conference (Glasgow, 1969), p. 73.

63 Labour Party of Wales papers, Welsh Council of Labour papers, Executive committee minutes, 20 February 1967 and 13 May 1968.

64 This account is based on Mitchell Library, Scottish Labour Party papers, TD 1384/1/5, Scottish Council executive committee minutes, 16 December 1967, 13 January, 11 May and 14 September 1968, 13-14 September 1969, and 21 March 1970.

65 NLS, George Lawson papers, Acc 9588/65, Scottish Labour Group, Executive committee report for submission to group meeting, 5 March 1968, and Memo by G. Lawson and R. Buchanan, 11 December 1968.

66 Mackintosh papers, Democracy; Scotsman, 2 November 1963.

67 A. Eadie and J. Sillars, Don't Butcher Scotland's Future (Glasgow, 1969).

68 Sixty-Seventh Annual Conference of Labour, pp. 174-6.

69 PRO, HO 221/39, Evidence submitted by Edinburgh Central CLP to the Royal Commission on the Constitution, n.d. (but October 1968); HO 221/ 41, Memorandum of written evidence to the Commission on the Constitution by Edinburgh City Labour Party.

70 Labour Party of Wales papers, Welsh Council of Labour papers, Executive committee minutes, 20 November 1967 and 9 December 1968; CAB 134/ 2697, Minutes of the ministerial committee on devolution for Scotland and Wales, 13 March 1968.

71 Labour Party of Wales papers, File 106, Machinery of government, n.d. (but 1969).

72 This paragraph is based on NLS, Arthur Woodburn papers, Acc 7656/Box 1/File 1, Crossman to Woodburn, 10 November 1967; Griffiths papers, C/ 3/15, Crossman to Griffiths, 28 November 1967; CAB 130/390, Minutes of meetings held to discuss devolution to Scotland and Wales, 18 July, 23 and 28 October 1968; R. H. S. Crossman, Diaries of a Cabinet Minister. Volume II (1977), pp. 610-11.

73 K. O. Morgan, Callaghan. A Life (Oxford, 1997), pp. 361-2.

74 Sixty-Seventh Annual Conference of Labour, p. 184.

75 HO 221/176, Northern Regional Council of the Labour Party, Evidence for the Crowther Commission, n.d.; T. Dan Smith, An Autobiography (Newcastle upon Tyne, 1970), 86-107. 
76 HLG 131/756, West Midlands Labour Party Working Party on Regional Government, Discussion paper, August 1969.

77 HO 221/99, Trades Union Congress, Observations submitted to the Commission on the Constitution, 3 February 1970.

78 HO 221/73, Evidence of the Labour Party in Wales to the Commission on the Constitution, 7 January 1970.

79 D. Leach, 'Scottish Labour in perspective', Socialist Commentary, March 1969; Wood, 'Scottish Labour', pp. 106-7; HO 221/142, The Government of Scotland, Evidence of the Labour Party in Scotland to the Commission on the Constitution, March 1970.

80 Parliamentary Debates (Hansard), 5th Series, Volume 784, House of Commons Official Report, Session 1968-9, columns 1461-4.

81 D. Regan, 'Start not end of a debate', Socialist Commentary, August 1969.

82 PREM 13/2763, Thomson to Wilson, 23 June, 30 July and 4 August 1969; PREM 13/2763, A. Crosland, Redcliffe-Maud: the options, October 1969.

83 BRO, Bristol West CLP papers, 38598/1/g, GMC minutes, 31 July and 25 September 1969.

84 Sixty-Eighth Annual Conference of Labour, pp. 152-4.

85 LPA, Regional and Local Government Advisory Committee (RLGAC) papers and minutes, 22 October 1969, Report of regional conferences on local government reform in England, Re. 522, October 1969, and Principles for local government reform in England, Re. 528, October 1969; Sixty-Eighth Annual Conference of Labour, pp. 149-64.

86 RLGAC papers, Local government reform in England: the White Paper and the National Executive Committee suggestions compared, Re. 588, February 1970.

87 A. Crosland, Socialism Now (1974), pp. 173-89.

88 A. H. Halsey, 'Government against poverty in school and community', in D. Wedderburn (ed.), Poverty, Inequality and Class Structure (Cambridge, 1974); R. Kraushaar, 'Policy without protest: the dilemma of organising for change in Britain', in M. Harloe (ed.), New Perspectives in Urban Change and Conflict (1981); M. Mayo, 'The history and early development of CDP', in R. Lees and G. Smith (eds), Action-Research in Community Development (1975).

89 CAB 165/665, Crossman to Wilson, 1 August 1968.

90 HO 291/1420, Working party on community development, Draft report to ministers, n.d.; PRO, BN 29/1392, Community Development Project departmental responsibility, n.d. (but October 1970), pp. 1-2.

91 CAB 152/111, Press release for speech by R. Crossman, 14 February 1969.

92 HO 389/12, Community Development Project, March 1970, p. 3.

93 BN 29/1392, Otton to Thomas, 5 October 1970.

94 BN 29/1345, Community development, Project progress report, July 1969, pp. 1-2; CAB 152/114, J. O. Bennington, Meeting with representatives of central and regional services, 13 April 1970, and CDP Central Steering Group minutes, 21 July 1970.

95 HO 389/12, J. Banks, Meeting in Liverpool, 17 April 1970.

96 HO 389/12, J. O. Bennington, Report of the Director of the Community Development Project, 5 March 1970.

97 Halsey, 'Government against poverty', p. 125.

98 New Society, 16 January and 20 March 1969.

99 J. Callaghan, Time and Chance (1987), pp. 237-9; J. Gyford, The Politics of Local Socialism (1985), pp. 26-36; Kraushaar, 'Policy without protest', p. 105.

100 A. Lyon, 'A Labour view', in M. Loney and M. Allen (eds), The Crisis of the Inner City (1979), pp. 23-4. 
101 A. Barker, 'Participation in politics', in B. Lapping and G. Radice (eds), More Power to the People. Young Fabian Essays on Democracy in Britain (1968); I. Bing, 'New approaches to democracy', in I. Bing (ed.), 'The Labour Party. An organisational study', Fabian Tract, 407 (1971), p. 20.

102 Sixty-Eighth Annual Conference of Labour, p. 156.

103 Short, Whip, p. 112; Wilson, Governance, p. 202.

104 Sixty-Ninth Annual Conference of Labour, pp. 274-9.

105 RLGAC papers, Participation: a draft paper for the 1970 local government conference, Re. 545, November 1969; Sixty-Ninth Annual Conference of Labour, p. 275.

106 LPA, NEC minutes, Working party on political education, Report, 13 September 1967.

107 LMA, J. W. Raisin papers, Acc 2783/JWR/ORG/68/51 and 87, organiser's reports.

108 Bing, 'New approaches', p. 24.

109 Sixty-Eighth Annual Conference of Labour, pp. 29, 355-6; NEC Home Policy Sub-Committee minutes, 12 May 1969, Participation 1969, Re. 453, May 1969.

110 Modern Records Centre, Handsworth CLP papers, MSS 8/5/21, Labour Party Research Department, Participation '69, Women and social security: a short report, Information Papers, No. 50 February 1970; see also SixtyNinth Annual Conference of Labour, p. 37.

111 Labour Party, Now Britain's Strong Let's Make It a Great Place to Live In (1970), pp. 20-5.

112 Mackintosh papers, Dep 323/44/1, Democratic reform and economic planning, May 1966; and HO 221/84, J. P. Mackintosh, Evidence for the Crowther Commission, n.d.

113 CAB 151/63, Hart to Greenwood, 10 July 1969. 